2021:6(1):27-36

http://ojs.uho.ac.id/index.php/JIA

doi: http://dx.doi.org/10.37149/JIA.v6i1.14974

\title{
ANALISIS KELAYAKAN FINANSIAL USAHA HIDROPONIK DI KELURAHAN KAMBU KECAMATAN KAMBU KOTA KENDARI (STUDI KASUS HIDROPONIK FAPERTA)
}

\author{
Nilam Permatasari Boer ${ }^{1 *}$, Abdi ${ }^{1}$, Abdul Gafaruddin ${ }^{1)}$ \\ ${ }^{1}$ Department of Agribusiness, Faculty of Agriculture, Halu Oleo University Kendari 93232
}

${ }^{*}$ Corresponding author: nilampermatasari110299@gmail.com

To cite this article:

Boer, N., Abdi, A., \& Gafaruddin, A. (2021). Analisis Kelayakan Finansial Usaha Hidroponik di Kelurahan Kambu Kecamatan Kambu Kota Kendari (Studi Kasus: Hidroponik Faperta). JIA (Jurnal Ilmiah Agribisnis) : Jurnal Agribisnis dan IImu Sosial Ekonomi Pertanian, 6(1), 27 - 36. doi:http://dx.doi.org/10.37149/jia.v6i1.14974

Received: November 05, 2020; Accepted: February 28, 2021; Published: February 28, 2021

\begin{abstract}
This research investigates the hydroponic business's revenue, analyzes the financial feasibility of a hydroponics business, and analyzes the sensitivity of the economic feasibility of a hydroponic business in Kambu Village, Kambu Sub-district, Kendari City (Studi Case: Hidroponik Faperta). This study aims to find out whether several factors could influence profits and prices in the business. This research was conducted in Kambu Village, Kambu Sub-district, Kendari City, from January 2020 to July 2020. The subject of this research is Hidroponik Faperta. This research uses the study case method. The data analyzed by the researcher is Financial Feasibility Analysis which includes as follows: Net Present Value Analysis, Net Benefit-Cost Ratio Analysis, Internal of Return Analysis, Payback Period Analysis, and Sensitivity Analysis. The results of this study obtained revenue in the first year of this business suffered a loss of Rp.6.438.600,- and in the second year revenue of Rp.175.032.000,-. The result of this research shows that there was also NPV of Rp.70.817.139,- obtained with a discount factor of $20 \%$, Net B/C of 2,16, IRR of $96,8 \%$, the Payback period for one year, four months, and seven days. The financial aspect analysis result could be summarized that business is feasible. Therefore, as the conclusion, this business is still feasible, despite a $15 \%$ decrease in vegetable production and $10 \%$ increase in seeds prices and hydroponic nutrition prices, each up $10 \%$ based on the calculation of the sensitivity analysis
\end{abstract}

Keywords: financial feasibility; hydroponic; revenue; sensitivity

\section{PENDAHULUAN}

Pertumbuhan jumlah penduduk terutama di daerah perkotaan tentunya akan dibarengi dengan meningkatnya kebutuhan penyediaan pangan, dengan semakin terbatasnya lahan di perkotaan yang dapat digunakan untuk bercocok tanam, tentunya perlu melakukan intensifikasi terhadap lahan-lahan yang masih tersisa.

Sektor pertanian merupakan sektor yang potensial untuk dikembangkan, salah satu subsektor dari pertanian yang cukup berpotensi di area perkotaan adalah komoditas holtikultura terutama sayur-sayuran yang menjadi kebutuhan sehari-hari untuk dikelola.

Komoditas holtikultura khususnya sayur-sayuran merupakan sumber vitamin dan mineral yang diperlukan manusia selain dari karbohidrat dan protein. Selain itu, perubahan gaya hidup sebagian penduduk perkotaan yang mulai perduli mengenai kesehatan dan bahaya residu bahan kimia dari pestisida mulai beralih dan memilih kepada bahan-bahan makanan yang ramah lingkungan seperti sayuran organik bebas pestisida(Widiyanto, 2019)

Keterbatasan lahan dan semakin meningkatnya jumlah permintaan sayur organik bebas pestisida ini membuka peluang usaha agribisnis yang cukup menjanjikan, usaha ini dapat dilakukan dengan cara bertani dengan sistem pertanian yang disebut hidroponik. Menurut Kusnawan dan Wijoyo sayuran hidroponik lebih menyehatkan, karena tidak tercemar pupuk buatan dan pestisida (Fitroni, 2018). 
Hidroponik dalam bentuk sederhana adalah membudidaya tanaman dengan memberikan nutrisi yang dibutuhkan oleh tanaman yang diberikan dalam airnya, bukan melalui tanah yang juga sering disebut " Dirtless gardening atau berkebun tanpa kotoran" (Damayanti, 2017)

Sistem Hidroponik sendiri termasuk cara bercocok tanam yang baru dikembangkan di Kota Kendari pada tahun 2017 dan masih banyak petani- petani yang jarang menggunakan sistem hidroponik karena usaha hidroponik ini membutuhkan biaya yang cukup besar untuk menjalankan usahanya, sehingga hanya orang-orang tertentu yang dapat menjalankan bisnis tersebut.

Sayur-sayur yang di produksi dengan menggunakan sistem ini tentunya mempunyai kualitas sangat baik daripada dengan sayur yang dibudidayakan menggunakan media tanah, namun yang menjadi kendala adalah biaya investasi dan modal awal yang diperlukan sangat tinggi, Biaya investasi dengan modal besar sering disebut sebagai kelemahan dalam teknologi hidroponik (Dijaya, 2018)

Investasi dengan modal awal yang tinggi digunakan untuk membangun instalasi hidroponik, sarana dan prasarana lainnya yang menjadikan pertimbangan harga jual sayur-sayur yang relatif tinggi dibandingkan dengan harga sayur-sayur yang tidak ditanam menggunakan sistem hidroponik dipasaran, sehingga perlu dikaji mengenai pelaksaan usaha hidroponik tersebut mulai dari budidayanya hingga pemasarannya yang akan menghasilkan pendapatan bagi usaha tersebut dan untuk melihat modal tersebut akan kembali dalam jangka waktu berapa lama. Dari perhitungan investasi nantinya dapat diketahui berapa besar manfaat usaha yang dilaksanakan akan mengalami keuntungan atau tidak serta layak atau tidak untuk di lanjutkan usahanya.

Usaha Hidroponik ini tentunya dihadapkan ketidakpastian yang dapat menyebabkan terjadinya perubahan yang mempengaruhi layaknya usaha (Pangaula, 2019), ketidakpastian ini dapat berupa penurunan jumlah produksi, Peningkatan harga benih dan nutrisi. Antisipasi akan terjadinya beberapa perubahan dari variabel dapat dilakukan dengan menggunakan analisis sensitivitas, analisis ini dapat melihat kemampuan usaha untuk menerima perubahan dari jumlah produksi, harga benih dan harga nutrisi. Hal inilah yang membuat peneliti melakukan penelitian dengan judul "Analisis Kelayakan Finansial Usaha Hidroponik di Kelurahan Kambu Kecamatan Kambu Kota Kendari (Studi Kasus Hidroponik Faperta)" yaitu untuk mengetahui penerimaan, kelayakan dan sensitifitas usahatani hidroponik yang memanfaatkan sedikit lahan dan pekarangan namun membudidayakan secara komersional.

\section{MATERI DAN METODE}

Penelitian ini dilaksanakan pada bulan Januari 2020 hingga Juli 2020 di tempat usaha Hidroponik Faperta Kelurahan Kambu Kota Kendari. Daerah penelitian ditentukan secara sengaja (Purposive), dengan pertimbangan bahwa usaha ini adalah satu-satunya usaha hidroponik yang dikembangkan secara komersial di Kelurahan Kambu.

Analisis data yang digunakan adalah kualitatif dan kuantitaif. Data kualitatif disajikan dalam bentuk deskriptif untuk menjelaskan mengenai gambaran tentang usaha hidroponik dan prospeknya. Sedangkan analisis kuantitatif digunakan untuk menyelesaikan perhitungan analisis kelayakan dengan cara menghitung mengalisis tingkat biaya, penerimaan, pendapatan, NPV, PP, IRR, dan Net B/C serta analisis sensitivitas usaha hidroponik tersebut

Untuk menghitung pendapatan usaha hidroponik yaitu dengan cara mengurangi total penerimaan dan total biaya (Winarti, 2016) sehingga dapat dirumuskan sebagai berikut :

Keterangan :

$$
\pi=\mathrm{TR}-\mathrm{TC}
$$

$\pi \quad=$ Pendapatan $(\mathrm{Rp})$

$\mathrm{TR}=$ Penerimaan Total $(\mathrm{Rp})$

$\mathrm{TC} \quad=$ Biaya Produk Total $(\mathrm{Rp})$

Menghitung Nilai Net Present Value (NPV) yaitu untuk menganalisis keuangan yang digunakan untuk mengukur layak tidaknya usaha hidroponik Faperta tersebut.

Keterangan:

$$
\mathrm{NPV}=\sum_{t=1}^{n} \frac{B t-C t}{(1+i)^{t}}
$$

$\mathrm{Bt} \quad=$ Manfaat pada tahun $\mathrm{t}$

$\mathrm{Ct} \quad=$ Biaya pada tahun $\mathrm{t}$

$\mathrm{i} \quad=$ Tingkat Discount Rate yang berlaku (Persen) 
Kriteria penilaian :

$$
\frac{1}{(1+i)^{t}}=\text { Discount Factor (DF) pada tahun ke- } \mathrm{t}
$$

Jika NPV $>0$, maka usaha layak atau menguntungkan

Jika $N P V<0$, maka usaha tidak layak atau merugikan

Jika $N P V=0$, maka usaha tidak menguntungkan dan tidak pula rugi

Net Benefit Cost Ratio adalah rasio dari jumlah net present value yang positif dengan jumlah net present value yang negatif.

$$
\mathrm{NET} \quad \mathrm{B} / \mathrm{C}=\frac{N P V(+)}{N P V(-)}
$$

Internal Rate of Return (IRR) digunakan untuk mencari tingkat bunga penerimaan kas dengan pengeluaran investasi. Adapun rumusnya secara sistematis menurut Sunyoto adalah sebagai berikut:

Keterangan :

$$
\mathrm{IRR}=\frac{\text { LABA USAHA }}{\text { MODAL SENDIRI }} \times 100 \% \quad \text { atau } \quad \mathrm{IRR}=i_{1}+\left(\frac{N P V 1}{N P V 1+N P V 2}\right)\left(i_{2}-i_{1}\right)
$$

$\mathrm{i}_{1} \quad=$ Discount rate menghasilkan NPV positif

$\mathrm{i}_{2} \quad=$ Discount rate menghasilkan NPV negatif

NPV1 $=$ NPV positif

NPV2 = NPV Negatif

Kriteria penilaian:

IRR > i maka bisnis layak untuk dijalankan

IRR $<$ i maka bisnis tidak layak untuk dijalankan

Payback period (PP) yaitu lamanya periode untuk mengembalikan modal investasi dari usaha hidroponik faperta ini. Adapun rumus Payback Period adalah sebagai berikut:

$$
\text { Payback Period }=\frac{\text { Investasi }}{\text { Kas Bersih pertahun }} \times 1 \text { tahun }
$$

Analisis Sensitivitas digunakan dengan cara mengganti variabel penting yaitu perubahan pada penurunan harga produk serta peningkatan harga benih dan harga nutrisi. Hasil dari analisis ini adalah nilai maksimum perubahan yang diperoleh usaha hidroponik faperta, jika yang terjadi melebihi presentase sensitivitas maka usaha dinyatakan tidak layak.

Pada analisis ini, ditaksirkan selain jumlah produksi, harga jual produk dan harga benih dan nutrisi tidak akan berubah. Elemen jumlah produksi dan harga jual produk, harga benih dan nutrisi dianalisis karena dapat mempengaruhi perolehan hasil yang disebabkan oleh serangan hama dan penyakit serta kestabilan harga sayuran hidroponik. Elemen harga benih dan nutrisi diambil karena menjadi elemen biaya terbesar pada biaya variabel, sehingga perubahannya akan mampu mempengaruhi layak dan tidak layaknya usaha hidroponik faperta

\section{HASIL DAN PEMBAHASAN}

\section{Gambaran Umum Hidroponik Faperta}

Usaha ini didirikan Pada bulan Oktober 2017, Usaha Hidroponik Faperta adalah usaha yang mengelola budidaya sayuran menggunakan sistem hidroponik NFT (Nutriet Film Teknique) dan Semi NFT. Jumlah Lubang Tanam pada awalnya sebanyak 3000 Lubang Tanam dan pada tahun kedua bertambah menjadi 6000 Lubang Tanam, sehingga hidroponik Faperta saat ini memiliki 9000 Lubang Tanam untuk melakukan budidaya sayuran hidroponiknya.

Usaha ini di kembangkan di dua tempat karena memanfaatkan lahan yang tersisa, Adapun lokasi utama usaha ini adalah laboratorium lapang percobaan 1 Fakultas Pertanian Universitas Halu Oleo, dengan luas area pada awalnya adalah $160 \mathrm{~m}^{2}$ dan pada tahun berikutnya di tambah hingga kini menjadi luas area hingga $900 \mathrm{~m}^{2}$. Sedangkan untuk lokasi kedua yaitu di pekarangan rumah yang beralamat di perumahan dosen Blok A dengan luas area $96 \mathrm{~m}^{2}$.

Usaha ini mulai dijalankan dan memproduksi sayuran hidroponik secara komersial, jenis sayuran membudidayakan sayuran seperti selada, sawi pakcoy, dan seledri. Sayuran yang paling mendominasi dibudidayakan pada Hidroponik Faperta adalah tanaman selada, Hal ini terjadi karena permintaan selada di pasaran sangat tinggi dibandingkan sawi pakcoy dan seledri. Adapun usaha yang bekerjasama dengan hidroponik faperta dalam penyediaan bahan baku sayuran seperti Hypermart, Indogrosir, KFC, Texas, Hotel Plaza Inn, Hotel Zenith, RM. Angkasa Nikmat, RM. Padang Sederhana, dan Pasar tradisional Se-Kota Kendari. 


\section{Biaya Produksi}

Biaya produksi adalah semua jenis biaya yang harus dikeluarkan untuk kebutuhan usahatani (Hamidah, 2014) dalam usaha Hidroponik Faperta melibatkan dua macam biaya yaitu biaya penanaman modal dan biaya operasional. Biaya penanaman modal adalah biaya yang diperlukan untuk pembelian barang-barang yang dapat digunakan berulangkali dalam proses produksi (Hamidah, 2015) seperti dalam pembangunan dan perbaikan proyek, terdiri dari gedung, peralatan,instalasi,mesin dan biaya lain yang berhubungan dengan pengembangan proyek dan bersifat jangka panjang. Biaya investasi dalam penelitian ini digunakan meliputi pengadaan instalasi, greenhouse, peralatan. Rincian Biaya investasi dari tahun ke nol dan tahun pertama pada usaha Hidroponik Faperta dapat dilihat pada Tabel 1. berikut ini:

Tabel 1. Rincian biaya penanaman modal pada usaha Hidroponik Faperta

\begin{tabular}{ccc}
\hline No & Investasi tahun ke- & Jumlah(Rp) \\
\hline 1 & Investasi Tahun Ke 0 & 34.500 .000 \\
2 & Investasi Tahun Ke 1 & 32.620 .000 \\
\hline & Jumlah & 67.120 .000 \\
\hline
\end{tabular}

Pada Tabel 1 menunjukan total biaya investasi yang dikeluarkan usaha Hidroponik Faperta, investasi yang paling banyak dikeluarkan adalah investasi instalasi hidroponik. Hal ini di karenakan instalasi yang digunakan pada tahun pertama seharga Rp20.000.000,- untuk 3000 Lubang Tanam dan pada tahun kedua seharga Rp30.000.000 untuk penambahan instalasi 6000 Lubang Tanam, Investasi yang ditambah ini merupakan investasi paling menunjang dalam usaha Hidroponik Faperta. Sedangkan biaya investasi terkecil adalah timbangan gantung digital dan gabus penampungan air $80 \mathrm{~L}$. Biaya Investasi merupakan biaya utama dan paling awal dikeluarkan untuk memenuhi kebutuhan berdirinya suatu usaha dan manfaatnya dapan bertahan dalam beberapa kurun waktu kedepan sehingga tidak habis dalam sekali produksi (Destriani, 2019) Tabel 2. juga menunjukan bahwa setiap setahun sekali ada biaya investasi yang diganti, terkait dengan sarana yang mudah rusak. Hal ini berkaitan dengan biaya penyusuta, karena setiap elemen investasi memiliki nilai beli dan umur ekonomisnya yang berbeda,sehingga perlu diperhitungkan satu persatu pada setiap elemen yang ada (Dijaya, 2018). Untuk biaya penyusutan dapat dilihat pada Tabel 2 dan Tabel 3 berikut ini:

Tabel 2. Perhitungan biaya penyusutan investasi usahsa Hidroponik Faperta tahun pertama.

\begin{tabular}{clcccccc}
\hline No & Komponen Biaya & Jumlah & Satuan & $\begin{array}{c}\text { Harga } \\
(\mathrm{Rp})\end{array}$ & $\begin{array}{c}\text { Total } \\
(\mathrm{Rp})\end{array}$ & $\begin{array}{c}\text { Umur } \\
\text { Ekonomis }\end{array}$ & $\begin{array}{c}\text { Beban } \\
\text { Penyusutan }\end{array}$ \\
\hline 1 & Instalasi & 3000 & $\begin{array}{c}\text { Lubang } \\
\text { Tanam }\end{array}$ & & 20.000 .000 & 5 & 4.000 .000 \\
\hline 2 & Mesin Air & 1 & Unit & 450.000 & 450.000 & 2 & 225.000 \\
\hline 3 & $\begin{array}{l}\text { Pompa Aquarium } \\
\text { 3m }\end{array}$ & 2 & Unit & 200.000 & 400.000 & 2 & 200.000 \\
\hline 4 & $\begin{array}{l}\text { Perbaikan } \\
\text { Greenhouse }\end{array}$ & 1 & Unit & & 10.000 .000 & 5 & 2.000 .000 \\
\hline 5 & $\begin{array}{l}\text { Timbangan } \\
\text { Digital }\end{array}$ & 2 & Unit & 75.000 & 150.000 & 1 & 150.000 \\
\hline 6 & $\begin{array}{l}\text { Timbangan } \\
\text { Manual }\end{array}$ & 1 & Unit & 200.000 & 200.000 & 5 & 40.000 \\
\hline 7 & Drum Air 600L & 1 & Unit & 900.000 & 900.000 & 5 & 180.000 \\
\hline 8 & Drum Air 300L & 2 & Unit & 300.000 & 600.000 & 5 & 120.000 \\
\hline 9 & Peralatan Las & 1 & Unit & 1.200 .000 & 1.200 .000 & 5 & 240.000 \\
\hline 10 & $\begin{array}{l}\text { Mesin Pemotong } \\
\text { Pipa }\end{array}$ & 1 & Unit & 300.000 & 300.000 & 5 & 60.000 \\
\hline 11 & Alat Bor Pipa & 1 & Unit & 300.000 & 300.000 & 5 & 60.000 \\
\hline Jumlah Biaya Investasi & & & & 34.500 .000 & & \\
\hline Total Biaya Penyusutan Pertahun & & & & & 7.275 .000 \\
\hline
\end{tabular}

Tabel 2. menunjukan bahwa besarnya biaya penyusutan pada tahun pertama sebesar Rp7.275.000,- biaya penyusutan investasi pada tahun pertama yang dikeluarkan oleh usaha Hidroponik Faperta ini berbeda pada tahun kedua, hal ini terjadi karena pada tahun kedua Hidroponik Faperta menambah sejumlah alat investasinya untuk lebih mengembangkan lagi 
jumlah produksinya. Lebih jelasnya, biaya penyusutan pada tahun kedua dapat dilihat pada Tabel 3. berikut ini:

Tabel 3. Perhitungan biaya penyusutan investasi usaha Hidroponik Faperta tahun kedua

\begin{tabular}{rlccrrrr}
\hline No & Komponen Biaya & Jumlah & Satuan & $\begin{array}{c}\text { Harga/unit } \\
(\mathrm{Rp})\end{array}$ & $\begin{array}{c}\text { Total } \\
(\mathrm{Rp})\end{array}$ & $\begin{array}{r}\text { Umur } \\
\text { Ekonomis }\end{array}$ & $\begin{array}{r}\text { Beban } \\
\text { Penyusutan }\end{array}$ \\
\hline 1 & Instalasi & 3000 & $\begin{array}{l}\text { Lubang } \\
\text { Tanam }\end{array}$ & & 20.000 .000 & 5 & 4.000 .000 \\
\hline 2 & Mesin Air & 1 & Unit & 450.000 & 450.000 & 2 & 225.000 \\
\hline 3 & $\begin{array}{l}\text { Pompa Aquarium } \\
\text { 3m }\end{array}$ & 2 & Unit & 200.000 & 400.000 & 2 & 200.000 \\
\hline 4 & $\begin{array}{l}\text { Perbaikan } \\
\text { Greenhouse }\end{array}$ & 1 & Unit & & 10.000 .000 & 5 & 2.000 .000 \\
\hline 5 & $\begin{array}{l}\text { Timbangan } \\
\text { Digital }\end{array}$ & 2 & Unit & 75.000 & 150.000 & 1 & 150.000 \\
\hline 6 & $\begin{array}{l}\text { Timbangan } \\
\text { Manual }\end{array}$ & 1 & Unit & 200.000 & 200.000 & 5 & 40.000 \\
\hline 7 & Drum Air 600L & 1 & Unit & 900.000 & 900.000 & 5 & 180.000 \\
\hline 8 & Drum Air 300L & 2 & Unit & 300.000 & 600.000 & 5 & 120.000 \\
\hline 9 & Peralatan Las & 1 & Unit & 1.200 .000 & 1.200 .000 & 5 & 240.000 \\
\hline 10 & $\begin{array}{l}\text { Mesin Pemotong } \\
\text { Pipa }\end{array}$ & 1 & Unit & 300.000 & 300.000 & 5 & 60.000 \\
\hline 11 & Alat Bor Pipa & 1 & Unit & 300.000 & 300.000 & 5 & 60.000 \\
\hline 12 & Instalasi & 6000 & Lubang & & 30.000 .000 & 5 & 6.000 .000 \\
\hline 13 & $\begin{array}{l}\text { Pompa Aquarium } \\
\text { 1,5m }\end{array}$ & 11 & Unit & 100.000 & 1.100 .000 & 2 & 550.000 \\
\hline 14 & $\begin{array}{l}\text { Pompa Aquarium } \\
\text { 3m }\end{array}$ & 1 & Unit & 200.000 & 200.000 & 2 & 100.000 \\
\hline 16 & Drum Air 300L & 2 & Unit & 300.000 & 600.000 & 5 & 120.000 \\
\hline 17 & Gabus Air 80L & 9 & Unit & 80.000 & 720.000 & 1 & 720.000 \\
\hline Jumlah Biaya Investasi & & & & 67.120 .000 & & \\
\hline Total Biaya Penyusutan Pertahun & & & & & & 14.765 .000 \\
\hline
\end{tabular}

Tabel 3. menunjukan biaya penyusutan investasi yang dikeluarkan oleh usaha Hidroponik Faperta sebesar Rp14.765.00,- karena terdapat penambahan investasi pada tahun kedua, maka biaya penyusutan tahun kedua ini merupakan penjumlahan antara biaya penyusutan investasi pada tahun pertama dan tahun kedua.

Biaya modal kerja adalah modal yang dikeluarkan untuk mendanai operasional perusahaan selama masih beroperasi (Kasmir \& Jakfar, 2017) dalam usaha Hidroponik Faperta biaya modal kerja yang dikeluarkan melibatkan variabel cost dan fixed cost. Adapun rinci biaya operasional yang dikeluarkan selama setahun dilihat pada Tabel 4 sebagai berikut:

Tabel 4. Perhitungan biaya modal kerja pada tahun pertama dan tahun kedua

\begin{tabular}{cccc}
\hline No & Biaya Modal Kerja & Tahun 1 & Tahun 2 \\
\hline 1 & Biaya Variabel & 14.478 .600 & 35.568 .000 \\
\hline 2 & Biaya Tetap & 54.000 .000 & 54.000 .000 \\
\hline & Total & 68.478 .600 & 89.568 .000 \\
\hline
\end{tabular}

Tabel 4 menjelaskan mengenai perbedaan dari kedua biaya operasional,yaitu terletak pada biaya variabelnya. Pada tahun kedua Hidroponik Faperta menambah investasi utama berupa instalasi 6000 Lubang Tanam sehingga mempengaruhi penambahan biaya variabel . Adapun lebih rincinya komponen biaya modal kerja yang dikeluarkan di Hidroponik Faperta dalam sebulan setiap tahunnya dijelaskan pada Tabel 5 dan Tabel 6 . sebagai berikut:

Tabel 5. menunjukan biaya variabel yang digunakan terbesar adalah penggunaan nutrisi AB Mix sebanyak $30 \mathrm{~L}$, selanjutnya pembelian bensin sebagai bahan bakar kendaraan untuk pengantaran sayur. Sedangkan biaya tetap yang dikeluarkan oleh Hidroponik Faperta adalah biaya tenaga kerja, hal ini didukung dengan penelitian Fitroni (2018) yang menjelaskan biaya tetap 
terbesar yang dikeluarkan Carnegie Hydroponics adalah untuk membiayai 2 karyawan Carnegie Hydroponics sebesar Rp 39.600.000 tiap tahunnya.

Tabel 5. Biaya modal kerja dalam sebulan pada tahun pertama

\begin{tabular}{|c|c|c|c|c|c|}
\hline No & Komponen Biaya & Jumlah & Satuan & Harga/unit (Rp) & Total (Rp) \\
\hline \multicolumn{6}{|c|}{ Biaya Variabel } \\
\hline 1 & Benih Selada $10 \mathrm{gr}$ & 0,33 & Bungkus & 27.000 & 9.000 \\
\hline 2 & Benih Sawi Pakcoy $10 \mathrm{gr}$ & 0,67 & Bungkus & 15.000 & 10.000 \\
\hline 3 & Benih Seledri & 0,17 & Bungkus & 15.000 & 2.550 \\
\hline 4 & Nutrisi AB Mix & 30 & Liter & 15.000 & 450.000 \\
\hline 5 & Rockwoll $100 \times 20 \mathrm{~cm}$ & 2 & Slop & 80.000 & 160.000 \\
\hline 6 & plastik packing & & Roll & & 150.000 \\
\hline 7 & Bensin & 30 & Liter & 7.500 & 225.000 \\
\hline 8 & Listrik & 4 & KWH & 50.000 & 200.000 \\
\hline \multicolumn{5}{|c|}{ Jumlah Biaya Variabel per Bulan } & 1.206 .550 \\
\hline \multicolumn{6}{|c|}{ Biaya Tetap } \\
\hline 9 & Tenaga Kerja & 3 & Orang & 1.500 .000 & 4.500 .000 \\
\hline \multirow{2}{*}{\multicolumn{5}{|c|}{$\begin{array}{c}\text { Jumlah biaya tetap per bulan } \\
\text { Jumlah biava modal keria per bulan }\end{array}$}} & 4.500 .000 \\
\hline & & kerja $\mathrm{p}$ & bulan & & 5.706 .550 \\
\hline
\end{tabular}

Jumlah biaya modal kerja yang digunakan Hidroponik Faperta selama sebulan pada tahun pertama adalah sebesar Rp5.706.550.

Tabel 6. Biaya modal kerja dalam sebulan pada tahun kedua

\begin{tabular}{|c|c|c|c|c|c|}
\hline No & Nama & Jumlah & Satuan & Harga (Rp) & Total $(\mathrm{Rp})$ \\
\hline \multicolumn{6}{|c|}{ Biaya Variabel } \\
\hline 1 & Benih Selada 10gr & 1 & Bungkus & 27.000 & 27.000 \\
\hline 2 & Benih Sawi Pakcoy 10gr & 2 & Bungkus & 15.000 & 30.000 \\
\hline 3 & Benih Seledri $20 \mathrm{gr}$ & 0,5 & Bungkus & 15.000 & 7.500 \\
\hline 4 & Nutrisi AB Mix & 90 & Liter & 15.000 & 1.350 .000 \\
\hline 5 & Rockwoll $100 \times 20 \mathrm{~cm}$ & 4 & Slop & 80.000 & 320.000 \\
\hline 6 & plastik packing & 1 & Roll & 500.000 & 500.000 \\
\hline 7 & Bensin & 30 & Liter & 7.650 & 229.500 \\
\hline 8 & Listrik & 4 & KWH & 125.000 & 500.000 \\
\hline \multicolumn{5}{|c|}{ Jumlah Biaya Variabel per Bulan } & 2.964 .000 \\
\hline \multicolumn{6}{|c|}{ Biaya Tetap } \\
\hline 9 & Tenaga Kerja & 3 & Orang & 1.500 .000 & 4.500 .000 \\
\hline \multicolumn{5}{|c|}{ Jumlah Biaya Tetap per Bulan } & 4.500 .000 \\
\hline & \multicolumn{4}{|c|}{ Jumlah Biaya Modal Kerja per bulan } & 7.464 .000 \\
\hline
\end{tabular}

Tabel 6. menunjukan biaya variabel yang digunakan terbesar adalah penggunaan nutrisi AB Mix sebanyak $90 \mathrm{~L}$, selanjutnya pembelian bensin sebagai bahan bakar kendaraan untuk pengantaran sayur. Sedangkan biaya tetap yang dikeluarkan oleh Hidroponik Faperta adalah biaya tenaga kerja. Adapun Jumlah biaya modal kerja yang digunakan selama sebulan pada tahun pertama adalah sebesar Rp7.464.000.

\section{Produksi dan Harga Produksi}

Produksi merupakan hasil akhir yang diperoleh untuk memenuhi permintaan konsumen. Hidroponik Faperta setiap harinya membudidayakan tiga jenis sayuran yaitu, selada, sawi pakcoy dan seledri. Jumlah produksi yang dihasilkan tidak selalu sama, hal ini terjadi karena setiap pembudidayaan memiliki tingkat persentase keberhasilan yang berbeda-beda. Hal ini terjadi karena faktor lingkungan yang mempengaruhi kapasitas dan kecepatan kecambah tumbuh (Rusmin dkk, 2014), selain itu pertumbuhan benih dipengaruhi oleh penggunaan pupuk yang dapat mempengaruhi pertumbuhan vegetatif tanaman (Silvia dkk, 2016) pemberian pupuk dengan takaran yang sesuai akan mempengaruhi pertumbuhan akar,daun dan batangnya (Hayati dkk, 2012) sehingga hidroponik faperta mempertimbangkan keberhasilan tubuh bibitnya adalah 50-60\% Adapun frekuensi produksi usaha Hidroponik Faperta dalam sebulan dapat dilihat pada Tabel 7. dan 8. berikut ini: 
Tabel 7. Produksi sayuran hidroponik di Hidroponik Faperta dalam sebulan pada tahun pertama

\begin{tabular}{|c|c|c|c|c|c|c|c|}
\hline No & $\begin{array}{l}\text { Jenis } \\
\text { Sayur }\end{array}$ & $\begin{array}{l}\text { Lubang } \\
\text { Tanam }\end{array}$ & $\begin{array}{l}\text { \% yang } \\
\text { ditanam }\end{array}$ & $\begin{array}{l}\text { Populasi } \\
\text { Sayur }\end{array}$ & $\begin{array}{c}\% \text { Tingkat } \\
\text { Keberhasilan }\end{array}$ & $\begin{array}{c}\text { Jumlah } \\
\text { Sayur (Pot) }\end{array}$ & $\begin{array}{l}\text { Produksi } 15 \\
\text { pot }=1 \mathrm{~kg}\end{array}$ \\
\hline 1 & Selada & 3000 & $50 \%$ & 1500 & $55 \%$ & 825 & 55 \\
\hline 2 & Pakcoy & 3000 & $40 \%$ & 1200 & $55 \%$ & 660 & 44 \\
\hline 3 & Seledri & 3000 & $10 \%$ & 300 & $55 \%$ & 165 & 11 \\
\hline \multicolumn{3}{|c|}{ Total Produksi } & $100 \%$ & 3000 & & 1650 & 110 \\
\hline
\end{tabular}

Tabel 7 menunjukan produksi tertinggi yaitu pada jenis sayuran tanaman selada, hal ini di dukung karena banyaknya permintaan konsumen sehingga pada tahun pertama $50 \%$ lubang tanam dibudidayakan tanaman selada, dengan jumlah produksi sebanyak $55 \mathrm{Kg} /$ Bulan. Selanjutnya Produksi kedua tertinggi ada pada tanaman sawi pakcoy dengan persentase penanaman $40 \%$ dari total jumlah lubang tanam, menghasilkan produksi sebanyak $44 \mathrm{Kg} / \mathrm{Bulan}$. Produksi paling rendah ada pada tanaman seledri dengan persentase penanaman $10 \%$ dari total jumlah lubang tanam, menghasilkan $11 \mathrm{~kg} /$ Bulan. Adapun tingkat keberhasilan dari setiap tanaman antara 50-60\% yang dapet mempengaruhi jumlah produksi di usaha Hidroponik Faperta, sedangkan harga perkilo gramnya secara berturut-turut adalah Rp50.000.- untuk perkilo gram selada, Rp40.000,- untuk perkilo gram sawi pakcoy, dan Rp60.000,- untuk perkilo gram Seledri.

Tabel 8. Produksi sayuran hidroponik di Hidroponik Faperta dalam sebulan pada tahun kedua

\begin{tabular}{cccccccc}
\hline No & $\begin{array}{c}\text { Jenis } \\
\text { Sayur }\end{array}$ & $\begin{array}{c}\text { Lubang } \\
\text { Tanam }\end{array}$ & $\begin{array}{c}\% \text { yang } \\
\text { ditanam }\end{array}$ & $\begin{array}{c}\text { Populasi } \\
\text { sayur }\end{array}$ & $\begin{array}{c}\text { \% tingkat } \\
\text { keberhasilan }\end{array}$ & $\begin{array}{c}\text { Jumlah } \\
\text { Sayur (Pot) }\end{array}$ & $\begin{array}{c}\text { Produksi } 15 \\
\text { Pot = } 1 \mathrm{~kg}\end{array}$ \\
\hline 1 & Selada & 9000 & $70 \%$ & 6300 & $75 \%$ & 4725 & 315 \\
\hline 2 & Pakcoy & 9000 & $20 \%$ & 1800 & $75 \%$ & 1350 & 90 \\
\hline 3 & Seledri & 9000 & $10 \%$ & 900 & $75 \%$ & 675 & 45 \\
\hline \multicolumn{2}{l}{ Total Produksi } & $100 \%$ & 9000 & & 6750 & 450 \\
\hline
\end{tabular}

Tabel 8. menunjukan produksi tertinggi yaitu tetap pada jenis sayuran tanaman selada, pada tahun kedua $70 \%$ lubang tanam dibudidayakan tanaman selada, dengan jumlah produksi sebanyak $315 \mathrm{Kg} /$ Bulan. Selanjutnya Produksi kedua tertinggi ada pada tanaman sawi pakcoy dengan persentase penanaman $20 \%$ dari total jumlah lubang tanam, menghasilkan produksi sebanyak $90 \mathrm{Kg} /$ Bulan. Produksi paling rendah ada pada tanaman seledri dengan persentase penanaman $10 \%$ dari total jumlah lubang tanam, menghasilkan $45 \mathrm{~kg} /$ Bulan. Adapun tingkat keberhasilan dari setiap tanaman antara $70-80 \%$ yang dapat mempengaruhi jumlah produksi di usaha Hidroponik Faperta, sedangkan harga perkilo gramnya tidak mengalami perubahan yakni secara berturut-turut adalah Rp50.000.- untuk perkilo gram selada, Rp40.000,- untuk perkilo gram sawi pakcoy, dan Rp60.000,- untuk perkilo gram Seledri.

\section{Penerimaan}

Penerimaan yang dibahas pada penelitian ini adalah jumlah produksi dikali dengan harga perkilo gram nya dalam sebulan (Dijaya, 2018). Adapun penerimaan setiap bulannya dapat di rincikan sebagai berikut:

Tabel 9. Penerimaan Setiap bulan pada tahun pertama

\begin{tabular}{clcccc}
\hline No & Jenis Sayur & Produksi & Satuan & Harga/Satuan $(\mathrm{Rp})$ & Total $(\mathrm{Rp})$ \\
\hline 1 & Selada & 55 & $\mathrm{Kg}$ & 50.000 & 2.750 .000 \\
\hline 2 & Sawi Pakcoy & 44 & $\mathrm{Kg}$ & 40.000 & 1.760 .000 \\
\hline 3 & Seledri & 11 & $\mathrm{Kg}$ & 60.000 & 660.000 \\
\hline \multicolumn{7}{c}{ Total Penerimaan } \\
\hline
\end{tabular}

Tabel 9. menunjukkan jumlah penerimaan perbulan pada tahun pertama yang diterima oleh hiroponik Faperta, penerimaan terbesar diperoleh dari penjualan selada sebesar $\mathrm{Rp} 2.750 .000$ sedangkan penerimaan terkecil yang diperoleh dari penjualan seledri sebesar $\mathrm{Rp} 660.000$. sehingga total penerimaan dalam sebulan hidroponik faperta sebesar Rp 5.170.000.

Tabel 10. menunjukkan jumlah penerimaan perbulan pada tahun pertama yang diterima oleh hidroponik Faperta, penerimaan terbesar diperoleh dari penjualan selada sebesar Rp15.750.000 sedangkan penerimaan terkecil yang diperoleh dari penjualan seledri sebesar Rp2.700.000. sehingga total penerimaan dalam sebulan hidroponik faperta sebesar Rp 22.050.000. 
Tabel.10. Penerimaan setiap bulan pada tahun kedua

\begin{tabular}{clcccr}
\hline No & Jenis Sayur & Produksi & Satuan & Harga/Satuan $(\mathrm{Rp})$ & Total $(\mathrm{Rp})$ \\
\hline 1 & Selada & 315 & $\mathrm{Kg}$ & 50.000 & 15.750 .000 \\
\hline 2 & Sawi Pakcoy & 90 & $\mathrm{Kg}$ & 40.000 & 3.600 .000 \\
\hline 3 & Seledri & 45 & $\mathrm{Kg}$ & 60.000 & 2.700 .000 \\
\hline \multicolumn{7}{c}{ Total Penerimaan } \\
\hline
\end{tabular}

Penerimaan setiap tahunnya adalah hasil perkalian penerimaan dalam sebulan selama 12 bulan. berikut Penerimaan setiap tahunnya dijelaskan pada Tabel 11 berikut ini:

Tabel 11. Penerimaan setiap tahun usaha Hidroponik Faperta

\begin{tabular}{ccc}
\hline No & Tahun & Penerimaan (Rp) \\
\hline 1 & Des 2017- Nov 2018 & 62.040 .000 \\
\hline 2 & Des 2018- Nov 2019 & 264.600 .000 \\
\hline
\end{tabular}

Tabel 12. menunjukan penerimaan usaha Hidroponik Faperta setiap tahunnya berbeda karena terdapat penambahan jumlah lubang tanam pada tahun kedua. Pada tahun pertama, produksi usaha Hidroponik Faperta menghasilkan sebanyak $110 \mathrm{~kg}$ dari total keselurahan sayuran yang dihasilkan dengan penerimaan sebesar Rp5.170.000,- /bulan, sehingga selama setahun penerimaan yang diperoleh Hidroponik Faperta adalah sebesar Rp62.040.000,Sedangkan pada tahun kedua, produksi usaha Hidroponik Faperta menghasilkaan sebanyak $450 \mathrm{~kg}$ dari total keseluruhan sayuran yang dihasilkan dengan penerimaan sebesar Rp22.050.000,-/bulan, sehinga setahun penerimaan yang diperoleh Hidroponik Faperta pada tahun kedua adalah sebesar Rp264.600,--

\section{Pendapatan}

Pendapatan yang dimaksud dalam penelitian adalah penerimaan yang diterima oleh Hiroponik Faperta dikurangi dengan biaya operasional yang dikeluarkan setiap tahunnya, hal ini disajikan pada Tabel 12. berikut ini:

Tabel 12. Pendapatan usaha hidroponik faperta setiap tahunnya

\begin{tabular}{ccccc}
\hline No & Tahun & $\begin{array}{c}\text { Penerimaan } \\
(\mathrm{Rp})\end{array}$ & $\begin{array}{c}\text { Biaya Operasional } \\
(\mathrm{Rp})\end{array}$ & $\begin{array}{c}\text { Pendapatan } \\
(\mathrm{Rp})\end{array}$ \\
\hline 1 & Des 2017- Nov 2018 & 62.040 .000 & 68.478 .600 & $(6.438 .600)$ \\
\hline 2 & Des2018 - Nov 2019 & 264.600 .000 & 89.568 .000 & 175.032 .000 \\
\hline
\end{tabular}

Tabel 12. menunjukkan pendapatan pertahunnya usaha Hidroponik setiap tahunnya berbeda, hal ini terjadi seperti penjelasan sebelumnya karena terdapat perbedaan jumlah produksi yang dihasilkan. Pada tahun pertama usaha Hidroponik pendapatan bersih (Net Benefit) belum bisa menutupi biaya operasionalnya. sehingga pendapatan usaha ini mengalami kekurangan biaya operasional sebesar Rp.6.438.600,- dan pada tahun kedua usaha Hidroponik Faperta mulai memperoleh pendapatan bersih sebesar Rp175.032.000,-. Hal ini didukung pernyataan bahwa data pendapatan mampu melihat seberapa besar keuntungan atau kerugian usaha tersebut (Rindyani, 2011)

\section{Penilaian Kelayakan Finansial}

Analisis yang digunakan dalam menilai kelayakan usaha Hidroponik Faperta ini diantaranya adalah Net Present Value (NPV), Payback Period (PP), Internal Rate of Return (IRR),Net Benefit Cost Rasio (Net B/C), dan Analisis Sensitivitas.

\section{Net Present Value (NPV)}

Berdasarkan hasil kalkulasi analisis Net Present Value (NPV) menunjukan bahwa nilai bersih sekarang (NPV) pada discount factor (Df) 20\% sebesar Rp70.817.139,- sampai usaha hidroponik ini berjalan 2 tahun angka ini menunjukkan bahwa usaha Hidroponik Faperta menguntungkan dan layak untuk diusahakan, menurut penelitian Wahyu (2018) jika NPV yang diperoleh positif atau lebih besar dari nol, maka usaha menguntungkan layak untuk tetap dijalankan. Melihat ini, diharapkan usaha Hidroponik Faperta dapat memperluas jaringan usahanya khususnya dalam bidang pemasaran menglihat Net Present Value yang dihasilkan sebesar Rp70.817.139,- 


\section{Benefit Cost Rasio (Net B/C)}

Net B/C merupakan perbandingan antara NPV positif dan NPV negatif. Net B/C ini digunakan untuk mengetahui perbandingan antara nilai manfaat sekarang dengan nilai dan biaya sekarang pada tingkat discout factor yang berlaku yaitu $20 \%$ sebesar $2,16 \%$ yang berarti bahwa usaha Hidroponik Faperta ini layak untuk diusahakan karena nilai yang diperoleh lebih besar dari satu (Net B/C $>1)$, seperti yang telah disebutkan dalam kriteria penilaian investasi apabila Net $\mathrm{B} / \mathrm{C}>1$ (Firdaus, 2012) maka usaha tersebut menguntungkan dan layak untuk tetap dijalankan, oleh karena itu diharapkan agar usaha Hidroponik Faperta dapat terus dijalankan karena nilai Net B/C yang diperoleh cukup tinggi

\section{Internal Rate Of Return (IRR)}

Internal Rate of Return dipakai untuk mengetahui sampai sejauh mana pemilik Hidroponik Faperta mampu mengembalikan sejumlah modal yang diinvestasikannya diperoleh nilai IRR sebesar 96,8\%. Hal ini menunjukan usaha Hidroponik Faperta akan mampu bertahan sekalipun terjadi kenaikan tingkat discount factor sebesar 100\% (Sunyoto, 2014) dengan demikian, berdasarkan kriteria IRR maka usaha Hidroponik Faperta layak untuk diusahakan karena tingkat pengembalian dana berupa modal yang diperoleh lebih tinggi dari tingkat discount factor $20 \%$.

\section{Payback Period (PP)}

Payback Period (PP) yaitu kurun waktu pengembaliannya investasi yang telah dikeluarkan melalui keuntungan yang diperoleh dari usaha hidroponik (Arifin Dkk, 2017) Jangka waktu kembalinya investasi pada usaha Hidroponik Faperta ini adalah 1 tahun 4 bulan 7 hari, yang artinya Hidroponik Faperta mampu mengembalikan modal investasinya pada jangka waktu tersebut. Pada perhitungan PP tahun pertama, Hidroponik Faperta belum bisa mengembalikan investasinya, dikarenakan pada tahun pertama usaha hidroponik masih ini belum bisa menutupi biaya operasional dengan keuntungan yang diperolehnya. Hal ini dapat dilihat pada hasil perhitungan pendapatan tahun pertama sehingga perhitungan PP dimulai setelah tahun kedua, karena pada tahun kedua ini, Hidroponik Faperta sudah mulai mendapatkan keuntungan dengan Payback Period (PP) sebensar 4,24 bulan (4 bulan, 7 hari)

\section{Analisis Sensitivitas}

Analisis sensitivitas digunakan untuk melihat seberapa jauh mana usaha Hidroponik Faperta mampu bertahan terhadap pengaruh-pengaruh yang akan terjadi akibat keadaankeadaan yang berubah. Hal ini sangat perlu, karena kelayakan usaha diawali atas proyeksi yang mengandung banyak ketidakpastian tentang yang terjadi di masa yang akan datang nanti (Rindyani, 2011) Analisis sensitivitas pada kondisi menurunnya jumlah produksi sayuran sebesar $15 \%$ dengan diskon faktor $20 \%$ diperoleh nilai NPV senilai Rp.36.099.639. Hasil menunjukkan bahwa usaha Hidroponik Faperta secara finansial layak, karena nilai NPV yang diperoleh adalah positif (+), nilai Net B/C yang diperoleh usaha Hidroponik Faperta sebesar 1,53. Hasil perhitungan ini menunjukkan bahwa usaha Hidroponik Faperta layak diusahakan secara finansial, karena nilai Net B/C lebih besar atau sama dengan 1. Nilai IRR yang diperoleh usaha Hidroponik Faperta sebesar 58,8\%. Hasil perhitungan ini menunjukan bahwa usaha Hidroponik Faperta secara finansial layak diusahakan, karena tingkat pengembalian modal yang dipeoleh lebih besar dari tingkat suku bunga yang berlaku yaitu $20 \%$.

Analisis sensitivitas pada kondisi kenaikan harga benih dan harga nutrisi masingmasing naik 10\% dengan discoun Factor 20\% di peroleh nilai NPV sebesar Rp. 69.166.839. Hasil menunjukkan bahwa usaha Hidroponik Faperta secara finansial layak, karena nilai NPV yang diperoleh adalah positif $(+)$, Net B/C yang didapatkano usaha Hidroponik Faperta sebesar 2,13. Hasil perhitungan ini menunjukkan bahwa usaha Hidroponik Faperta layak diusahakan secara finansial, karena nilai Net B/C lebih besar atau sama dengan 1. Nilai IRR yang diperoleh usaha Hidroponik Faperta sebesar 96\%. Hasil perhitungan ini menunjukan bahwa usaha Hidroponik Faperta secara finansial layak diusahakan, karena tingkat pengembalian modal yang diperoleh lebih besar dari tingkat suku bunga yang berlaku yaitu $20 \%$.

\section{KESIMPULAN DAN SARAN}

Pendapatan usaha hidroponik Faperta pada tahun pertama masih belum cukup menutupi biaya produksi nya yang dikeluarkan sehingga pendapatan usaha Hidroponik Faperta mengalami kekurangan sebesar Rp.6.438.600 dan pada tahun kedua, Hidroponik Faperta mulai dapat menutupi 
biaya produksi nya, sehingga pendapatan bersih yang di peroleh adalah sebesar Rp 175.032.000. Usaha Hidroponik Faperta di kelurahan Kambu, kecamatan Kambu, Kota Kendari dinyatakan layak secara finansial untuk diusahakan, dengan discount factor $20 \%$ dengan NPV yang diperoleh sebesar Rp. Rp70.817.139,-, Net B/C sebesar 2,16 dan IRR sebesar 96,8 \% dan Payback Period selama 1 tahun 4 bulan 7 Hari. Serta Usaha Hidroponik Faperta ini masih layak diusahakan meskipun terjadi penurunan jumlah produksi sayuran sebesar $15 \%$ dan kenaikan harga benih dan harga nutrisi masing-masing naik 10\%. Beberapa saran yang dapat disampaikan dalam hasil penelitian ini adalah bagi pemilik usaha diharapkan lebih memperhatikan peningkatan dan penurunan produksi sayuran hidroponik, sehingga hasil produksi yang diperoleh maksimum serta memperhatikan biaya investasi dan modal kerja yang dikeluarkan, sehingga dapat membuat pertimbangan untuk lebih mengembangkan usahanya. Sedangkan bagi pemerintah diharapkan dapat melakukan pelatihan terhadap petani lain untuk memanfaatkan lahan terbatas dengan cara bercocok tanam menggunakan sistem hidroponik

\section{REFERENSI}

Arifin, D. Z., Rocdiani, D., \& Noormansyah, Z. (2017). Analisis Kelayakan Finansial Usaha Sawi Hijau (Brassica juncea L.) Dengan Sitem Hidroponik NFT (Nutrient Film Technique) (Studi Kasus Pada Seorang Petani Sayuran Hidroponik di Desa Neglasari Kecamatan Pamarican Kabupaten Ciamis). Jurnal IImiah Mahasiswa AGROINFO GALUH, 4(1), 609-613.

Damayanti, A. (2017). Analisis Usahatani Selada Sistem Hidroponik dengan Sistem NFT di Kecamatan Tenggarong Seberang. Magrobis Journal, 17(1), 34-46.

Destriani, A. (2019). Analisis Kelayakan Usaha Hidroponik pada Komunitas Pecinta Hidroponik Pekalongan. Retrieved from https://202.124.205.241/handle/123456789/99274

Dijaya, P. K. (2018). Tingkat Profitabilitas dan kelayakan Finansial Sayuran Hidroponik Pada KUT Hidrotani Sejahtera (Studi Kasus: Desa Suka Maju, Kecamatan Sugga, Kabupaten Deli Serdang)Dijaya, P. K. (2018). Tingkat Profitabilitas dan kelayakan Finansial Sayuran Hidroponik Pa. Universitas Muhammadiyah Sumatera Utara.

Firdaus, M. (2012). Manajemen Agribisnis. Jakarta: Bumi Aksara.

Fitroni, F. (2018). Analisis Kelayakan Usaha Budidaya Sayur Hidroponik di Carnergie Hydroponics Kabupaten Bogor. Institut Pertanian Bogor.

Hamidah, E. (2014). analisis kelayakan dan sensitivitas usahatani kacang panjang varietas zebra ( Vigna sinensis L .) ( Study Kasus di Desa Pilanggot Kecamatan Tikung Kabupaten Lamongan ). Saintis, 6(1), 57-72.

Hamidah, E. (2015). analisis efisiensi dan sensitivitas usahatani mentimun (Cucumis sativus $L$ ) ( Study Kasus di Dusun Kedung Desa Kedungkumpul Kecamatan Sarirejo Kabupaten Lamongan ). Saintis, 7(2), 153-170.

Hayati, E., Mahmud, \& Faizal, R. (2012). Pengaruh Jenis Pupuk Organik dan VArietas Terhadap Pertumbuhan dan Hasil Tanaman Cabai (Capsicum annum L.). J. Floratek, 7(2), 173-181.

Kasmir, \& Jakfar. (2017). Studi Kelayakan Bisnis (Revisi). Depok: Kencana.

Pangaula, S. F. (2019). Analisis Kelayakan USaha Budidaya Usaha Budidaya Pertanian Terintegasi Selada dan Ikan Patin dengan Teknik Akuaponik di Surya Tani Farm, Desa Citoe, Kabupaten Sukabumi. Institut Pertanian Bogor.

Rindyani, R. (2011). Analisis kelayakan finansial budidaya melon hidroponik. Universitas Islam Negeri Syarif Hidayatullah.

Rusmin, Suwarno, F., Darwati, I., \& llyas, S. (2014). Pengaruh Suhu dan Media PerkecambahanTerhadap Viabilitas dan Vigor Benih Purwoceng untuk Menentukan Metode Pengujian Benih. Bul.Littro, 25(1), 45-52.

Silvia, M., H, S., Samharinto, \& GT. M. S., N. (2016). Produksi Tanaman Cabe Rawit (Capsicum frutescent L.) di Tanah Ultisol Menggunakan Bokashi Sampah Organik Rumah Tangga dan NPK. Enviro Scienteae, 12(1), 22-27.

Sunyoto, D. (2014). Studi Kelayakan Bisnis. Yogjakarta: CAPS (Center Academic Publishing Service).

Wahyu, H. (2018). Analisis Kelayakan Usaha Kangkung Hidroponik di Specta Farm Kabupaten Bogor. Institut Pertanian Bogor.

Widiyanto, A. (2019). Analisis Kelayakan Finansial Usaha Selada (Lactuca sativa L.). Chlorophyl, 12(1), 1-9.

Winarti, L. (2016). Anlisis Sensitivitas Usaha Pengolahan Kerupuk Ikan Pipih di Kecamatan Seruyan Hilir Kabupaten Seruyan. Ziraa'ah, 41(2), 177-182. 